\title{
PENGARUH KUALITAS LAYANAN \\ DALAM MEMBENTUK LOYALITAS PELANGGAN \\ PADA DEALER YAMAHA TUGU MAS BIMA
}

\author{
Muhammad \\ muhammad16.stiebima@gmail.com \\ Sekolah Tinggi Ilmu Ekonomi (STIE) Bima \\ Irma mardian \\ irmamardian@gmail.com \\ Sekolah Tinggi Ilmu Ekonomi (STIE) Bima
}

\begin{abstract}
Abstrak
Tujuan penelitian ini adalah untuk mengetahui pengaruh kualitas layanan dalam membentuk loyalitas pelanggan pada dealer Yamaha Tugu Mas Bima.Jenis penelitian yang digunakan adalah asosiatif dengan menggunakan pendekatan kuantitatif. Variabel penelitian terdiri dari: kualitas layanan (X), loyalitas pelanggan (Y). Penelitian menggunakan kuiesioner sebagai instrument dan diukur dengan menggunakan skala likert.Jumlah sampel yang digunakan dalam penelitian ini berjumlah 90 responden.Pengujian instrumen dengan menggunakan uji validitas dan uji reliabilitas.Analisis data meliputi analisis regresi sederhana, determinasi, korelasi dan uji $t$ menggunakan SPSS versi 22. Hasil persamaan regresi $Y=7,192+0,564 X$, determinasi sebesar 0,418 $(41,8 \%)$ yang berarti pengaruh kualitas layanan terhadap loyalitas pelanggan adalah sebesar $41,8 \%$ dan nilai $R$ (Koefisien Korelasi) sebesar 0,646 menunjukkan hubungan yang kuat antar variabel. Hasil penelitian menunjukan bahwa kualitas layanan berpengaruh positif dan signifikan terhadap loyalitas pelanggan pada Dealer Yamaha Tugu Mas Bima.
\end{abstract}

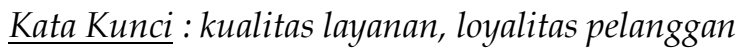

\section{Pendahuluan}

Meningkatnya intensitas persaingan menyebabkan perusahaan selalu memperhatikan kebutuhan, keinginan dan harapan pelanggan.Perusahaan berusaha untuk memenuhi apa yang pelanggan harapkan dengan cara menyediakan kualitas produk dan kualitas pelayanan yang baik. Kepuasan pelanggan terhadap perusahaan akanberdampak pada peningkatan penjualan yang menghasilkan keuntungan dan meningkatkan laba.

Yamaha Tugu Mas Bima merupakan salah satu dealer resmi Yamaha yang bergerak dalam bidang pemasaran sepeda motor merk Yamaha. Dalam usahanya, tidak hanya melakukan penjualan sepeda motor saja, akan tetapi juga menyediakan jasa service dan penggantian spare part.

Dengan semakin banyaknya jumlah pengguna sepeda motor tentu membutuhkan sarana dan prasarana untuk merawat maupun memperbaiki kendaraannya tersebut agar layak pakai, tidak kalah dengan produk baru dan dapat dijual dengan harga yang tinggi. Hal ini menimbulkan persaingan yang ketat terutama pada penyedia jasa service antara dealer resmi yang bekerjasama dengan merk-merk sepeda motor tertentu yang saling bersaing untuk mendapatkan konsumen.

Berdasarkan hasil observasi di Dealer Yamaha Tugu Mas,sebagai penyedia jasa ditemui beberapa masalah seperti pegawai dalam memberikan pelayanan perawatan dan perbaikan masih kurang cekatan dan teliti, dimana spare part sepeda motor kurang dicek dengan detail. Harga yang diberikan relatif lebih mahal dibandang bengkel yang lainnya, serta minimnya keterampilan dari mekaniknya dalam menanggapi 
permasalahan yang dihadapi pelanggan.Selain itu seringkali ada sparepartyang habis atau kosong karena keterlambatan pengiriman dari distributor sehingga konsumen ataupun pelanggan mencari di tempat lain. Hal-hal seperti ini dapat menyebabkan pelanggan kehilangan banyak waktu produktifnya. Sehingga berdampak pada pengurangan jumlah pelanggan di Yamaha Tugu Mas Bima

Berdasarkan uraian latar belakang tersebut maka peneliti tertarik untuk melakukanpenelitian tentang pengaruh kualitas layanan dalam membentuk loyalitas pelanggan pada Dealer Yamaha Tugu Mas Bima.

\section{Kajian Teori}

Kualitas pelayanan telah didefinisikan dengan berbagai sudut pandang, Tjiptono, 2005 mengemukakan bahwa kualitas pelayanan merupakan kegiatan keunggulan (excellence) yang diharapkan dan pengendalian atas keunggulan tersebut memenuhi kebutuhan pelanggan

Kepuasan pelanggan dapat dicapai dengan memberikan kualitas pelayanan yang optimal kepada pelanggan.Loyalitas pelanggan bisa terbentuk apabila pelanggan merasa puas dengan tingkat layanan yang diterima serta pelanggan cenderung untuk memilih produk atau jasa yang memiliki kelebihan. Parasuraman dalam Hardiyansyah (2011: 92) mendefinisikan penilaian kualitas layanan sebagai suatu pertimbangan global atau sikap yang berhubungan dengan keungggulan (superiority) dari suatu layanan. Adapun indikator kualitas layanan adalah tangibles, reliability, responsiveness, assurance, dan empati (Tjiptono, 2012).

Loyalitas pelanggan adalah komitmen yang dipegang secara mendalam untuk membeli atau mendukung kembali sebuah produk atau jasa yang disukai di masa depan meski pengaruh situasi dan usaha pemasaran berpotensi menyebabkan pelanggan beralih (Kotler dan Keller, 2008). Menurut Orel \& Kara (2014) indikator dari loyalitas pelanggan adalah: kesediaan pelanggan untuk pembelian dan service kembali, kesediaan pelanggan untuk merekomendasikan perusahaan kepada kerabatnya, menjadikan perusahaan sebagai prioritas utama, serta kesediaan pelanggan untuk hanya membicarakan hal positif tentang suatu perusahaan. Beberapa hasil penelitian pada objek penelitian yang berbeda menunjukkan bahwa ada hubungannya kualitas pelayanan dengan loyalitas konsumen (Christian dan Nuari, 2016). Demikian juga hasil penelitian Putri dan Utomo, 2017 yang menyatakan bahwa ada pengaruh langsung dan tidak langsung kualitas layanan terhadap loyalitas pelanggan

\section{Metode Penelitian}

\subsection{Jenis Penelitian}

Penelitian ini merupakan penelitian asosiatif bertujuan untuk mengetahui pengaruh atau hubungan antara dua variable atau lebih.Dalam hal ini untuk mengetahui pengaruh antara dua variabel yaitu variabel $X$ (kualitas layanan) terhadap variabel Y (loyalitas pelanggan).

\subsection{Populasi dan Sampel penelitian}

Populasi dalam penelitian ini adalahseluruh pelanggan yang melakukan pembelian ataupun service lebih dari satu kali di dealer Yamaha Tugu Mas Bima.Adapun teknik pengambilan sampel dalam penelitian ini adalah menggunakan purposive sampling, yaitu pengambilan anggota sampel dari populasi yang sesuai dengan kriteria.Jumlah sampel yang repesentatif menurutHair, 2006 adalah tergantung jumlah indikator dikalikan 5 sampai 10. Jumlah sampel dalam penelitian ini adalah :

jumlah sampel = jumlah indikator $\times 10$

$$
=9 \times 10=90 \text { responden }
$$




\subsection{Lokasi Penelitian}

Lokasi yang dijadikan tempat penelitian adalah Dealer Yamaha Tugu Mas di Kota Bima Nusa Tenggara Barat.

\section{Teknik Analisis Data}

\subsection{Uji Validitas}

Analisis validitas bertujuan untuk menguji apakah tiap butir pertanyaan benarbenar telah sahih, paling tidak kita dapat menetapkan derajat yang tinggi dari kedekatandata yang diperoleh dengan apa yang kita yakini dalam pengukuran. Suatu kuesioner dikatakan valid jika pertanyaan pada kuesioner mampu mengungkapkan sesuatu yang akan diukur oleh kuesioner tersebut (Ghozali, 2006). Uji validitas dilakukan dengan membandingkan nilai $r$ hitung lebih besar dari $r$ tabel sebesar 0,300

Tabel 1.hasil uji validitas kualitas layanan

\begin{tabular}{llll}
\hline Pernyataan & R hitung & R Tabel & Keterangan \\
\hline X.1 & 0,599 & 0,300 & VALID \\
X.2 & 0,663 & 0,300 & VALID \\
X.3 & 0,598 & 0,300 & VALID \\
X.4 & 0,584 & 0,300 & VALID \\
X.5 & 0,568 & 0,300 & VALID \\
X.6 & 0,599 & 0,300 & VALID \\
X.7 & 0,511 & 0,300 & VALID \\
X.8 & 0,653 & 0,300 & VALID \\
X.9 & 0,390 & 0,300 & VALID \\
X.10 & 0,663 & 0,300 & VALID \\
\hline
\end{tabular}

Uji validitas ini dilakukan untuk memastikan bahwa instrument yang digunakan menghasilkan data yang valid sehingga hasil penelitian tidak bias dan dapat dipertanggungjawabkan. Hasil uji validitas pada variabel kualitas layanan (Tabel 1) menunjukkan bahwa nilai $\mathrm{R}$ hitung semua lebih besar daripada 0,300 sehingga semua penyataan instrument penelitian dalam indikator kualitas layanan adalah valid.

Hasil uji validitas pada Tabel 2. menunjukkan nilai $r$ hitung seluruh pernyataan dalam kuesioner lebih besar dari $r$ tabel. Dengan demikian disimpulkan bahwa seluruh pernyataan dalam indikator loyalitas pelanggan adalah valid.

Tabel 2. Hasil uji validitas loyalitas pelanggan

\begin{tabular}{llll}
\hline Pernyataan & R hitung & R Tabel & Keterangan \\
\hline Y.1 & 0,483 & 0,300 & VALID \\
Y.2 & 0,314 & 0,300 & VALID \\
Y.3 & 0,482 & 0,300 & VALID \\
Y.4 & 0,430 & 0,300 & VALID \\
Y.5 & 0,647 & 0,300 & VALID \\
Y.6 & 0,660 & 0,300 & VALID \\
Y.7 & 0,511 & 0,300 & VALID \\
Y.8 & 0,659 & 0,300 & VALID \\
\hline
\end{tabular}




\subsection{Uji Reliabilitas}

Reliabilitas adalah tingkatan dimana suatu tes secara konsisten mengukur berapa pun hasil pengukuran itu.Reliabilitas dinyatakan dengan angka (biasanya sebagai suatu koefisien), koefisien yang tinggi menunjukkan reliabilitas yang tinggi. (Sugiyono, 2014:267). Kriteria pengujian reliabilitas yaitu, jika nilai koefisien alpha (Cronbach's Alpha) > 0,6 maka instrumen dinyatakan reliabel atau dapat dipercaya

Tabel 3. Hasil uji reliabilitas kualitas layanan

\begin{tabular}{lll}
\hline Cronbach's Alpha & $\begin{array}{l}\text { Cronbach's Alpha Based } \\
\text { on Standardized Items }\end{array}$ & N of Items \\
\hline 0,849 & 0,851 & 10 \\
\hline
\end{tabular}

Berdasarkan tabel 3. dapat diketahui bahwa nilai cronbach's alpha variabel kualitas layanan adalah 0,849 ini berarti 0,849>0,6. Dengan demikian item pernyataan instrumen variabel kepuasan pelanggan adalah reliabel.

Tabel 4. Hasil uji reliabilitas loyalitas pelanggan

\begin{tabular}{lll}
\hline Cronbach's Alpha & $\begin{array}{l}\text { Cronbach's Alpha Based } \\
\text { on Standardized Items }\end{array}$ & N of Items \\
\hline 0,783 & 0,777 & 8 \\
\hline
\end{tabular}

Berdasarkan tabel4. di atas dapat diketahui bahwa nilai cronbach's alpha variabel Loyalitas Pelangganadalah 0,783 ini berarti 0,783>0,6. Item pernyatan instrumen pada variabel loyalitas pelanggan adalah reliabel.

\subsection{Regresi Linear Sederhana}

Regresi sederhana didasarkan pada hubungan fungsional ataupun kausal satu variabel dependen.Manfaat dari analisis regresi adalah untuk membuat keputusan apakan naik dan menurunnya variabel dependen dapat dilakukan melalui peningkatan variabel independen atau tidak.(Sugiyono, 2014).Model Persamaan Regresi Linear Sederhana adalah seperti berikut ini :

$$
\mathbf{Y}=\mathbf{a}+\mathbf{b X}
$$

Dimana :

$\mathrm{Y}=$ Variabel response atau variabel akibat (Dependent)

$\mathrm{X}=$ Variabel predictor atau variabel faktor penyebab (independent)

$\mathrm{a}=$ konstanta

$\mathrm{b}=$ koefisien regresi (kemiringan); besaran response yang ditimbulkan oleh predictor.

\subsection{Korelasi Sederhana}

Analisis korelasi sederhana (Bivariate Correlation) digunakan untuk mengetahui keeratan hubungan antara dua variabel dan untuk mengetahui arah hubungan yang terjadi.Koefisien korelasi sederhana menunjukkan seberapa besar hubungan yang terjadi antara dua variabel.

\subsection{Koefisien Determinasi}

Koefisien determinasi pada regresi linear sering diartikan sebagai seberapa besar kemampuan semua variabel bebas dalam menjelaskan varians dari variabel terikatnya.Secara sederhana koefisien determinasi dihitung dengan mengkuadratkan koefisien korelasi $\left(\mathrm{R}^{2}\right)$. 


\subsection{Uji t}

Uji $\mathrm{t}$ pada dasarnya menunjukan seberapa jauh pengaruh satu variabel independen secara individual menerangkan variasi variabel terikat (Ghozali, 2006). Untuk melakukan pengujian $\mathrm{t}$ maka dapat digunakan dengan rumus sebagai berikut:

Dimana :

$$
\mathrm{t}=\beta \mathrm{n} / \mathrm{S} \beta \mathrm{n}
$$

$\mathrm{t}$ : mengikuti fungsi $t$ dengan derajat kebebasan $(\mathrm{df})$.

Bn: koefisien regresi masing-masing variabel.

$\mathrm{S} \beta \mathrm{n}$ : standar error masing-masing variabel.

Dasar pengambilan keputusan:

a. Jika probabilitas (signifikansi) $>0,05$ (a) atau $\mathrm{T}$ hitung $<\mathrm{T}$ tabel berarti hipotesa tidak terbukti maka $\mathrm{H} 0$ diterima Ha ditolak.

b. Jika probabilitas (signifikansi) $<0,05$ (a) atau $\mathrm{T}$ hitung $>\mathrm{T}$ tabel berarti hipotesa terbukti maka $\mathrm{H} 0$ ditolak dan Ha diterima, bila dilakukan uji secara parsial.

\section{Hasil Dan Pembahasan}

\subsection{Hasil Uji Regresi Linear Sederhana}

Tabel 5.hasil Regresi Linear Sederhana

\begin{tabular}{|c|c|c|c|c|c|}
\hline \multirow[t]{2}{*}{ Model } & Unc & Cofficiont & \multirow{2}{*}{$\begin{array}{l}\text { Standardized } \\
\text { Coefficients } \\
\text { Beta }\end{array}$} & \multirow[t]{2}{*}{$t$} & \multirow[t]{2}{*}{ Sig } \\
\hline & B & Std. Error & & & \\
\hline 1(Constant) & 7,192 & 2,818 & 0,646 & 2,553 & 0,12 \\
\hline Total X & 0,546 & 0,069 & & 7,944 & 0,000 \\
\hline
\end{tabular}

Dari hasil olah data diatas dengan SPSS maka diperoleh persamaan regresi linear sederhana sebagaimana terlihat pada table 5.berikut: $Y=7,192+0,546 X$. dimana jika kualitas layanan $(X)=0$ maka variabel loyalitas pelanggan adalah sebesar 7,192 dan apabila koefisien regresi kualitas layanan dinaikkan sebesar 1 kriteria maka loyalitas pelanggan akan mengalami kenaikan sebesar 0,546.

\subsection{Koefisien Korelasi}

Table 6. hasil Kofisien Korelasi

\begin{tabular}{llllll}
\hline Model & $\mathrm{R}$ & R square & $\begin{array}{l}\text { Adjusted } \\
\text { Square }\end{array}$ & $\begin{array}{l}\text { Std. Error of } \\
\text { the Estimate }\end{array}$ \\
\hline 1 & 0,646 & 0,418 & 0,411 & 2,356 \\
\hline
\end{tabular}

Berdasarkan nilai hitung kofisien korelasi sebesar 0,646 dan dibandingkan dengan nilai yang ada pada tabel interval kofisien korelasi (Sugiyono, 2014) menunjukan bahwa hubungan variabel kualitas layanan $(X)$ dengan variabel loyalitas pelanggan $(Y)$ pada Yamaha Tugu Mas Bima berada pada tingkat hubungan yang kuat yaitu antara 0,600,799 (kuat).

\subsection{Koefisien Determinasi}

Table 6.di atas menunjukkan besarnya koefisien determinasi (R square) sebesar 0,418 yang berarti pengaruh variabel kualitas layanan terhadap variabelloyalitas pelanggan adalah sebesar $41,8 \%$ dan sisanya sebesar $58,2 \%$ dipengaruhi oleh faktor lain yang tidak diteliti dalam penelitian ini.Artinya porsi kualitas layanan dalam mempengaruhi loyalitas pelanggan cukup tinggi.Hasil ini lebih tinggi daripada hasil penelitian Putri dan Utomo, 2017 yang menunjukkan 35,5 \% variasi variable kualitas pelayanan menjelaskan variasi loyalitas pelanggan 


\subsection{Uji t}

Adapun Hipotesis statistik penelitian yang akan diuji pada penelitian ini sebagaiberikut; $\mathrm{H}_{0}: \beta=\mathrm{o}$, tidak terdapat pengaruh kualitas layanan terhadap loyalitas pelanggan pada Dealer Yamaha Tugu Mas Bima. Dan $\mathrm{H}_{\mathrm{a}}: \beta \neq 0$, terdapat pengaruh kualitas layanan terhadap loyalitas pelanggan pada Dealer Yamaha Tugu Mas Bima.

Berdasarkan angka hasil uji t pada tabel 5 di atas maka diperoleh nilai uji t sebesar 7,944 dan nilai signifikan sebesar 0,000. Sedangkan nilai t tabel untuk $d k=n-2=88$ dan taraf kesalahan $5 \%$ uji dua pihak maka diperoleh nilai $t$ tabel sebesar 1,987. Dengan demikian nilai t hitung lebih besar dari $\mathrm{t}$ tabel $(7,944>1,987)$ maka $\mathrm{H}_{\mathrm{a}}$ diterima dan $\mathrm{H}_{\mathrm{o}}$ ditolak. Dengan kata lain hipotesis alternatif yang berbunyi terdapat pengaruh kualitas layanan terhadap loyalitas pelanggan pada Dealer Yamaha Tugu Mas Bima dapat diterima. Adapun nilai sig dari output SPSS sebesar 0,000 ternyata lebih kecil dari 0,05 ( sig $0,000<0,05$ ) maka dinyatakan pengaruh adalah signifikan. Sehingga dapat dikatakan ada pengaruh yang signifikan kualitas layanan terhadap loyalitas pelanggan pada Dealer Yamaha Tugu Mas Bima. Hasil ini sejalan dengan penelitian Chriastian dan Nuari, 2016; Rayani dan Rosinta, 2010; Darwin dan Kunto, 2014 yang menunjukkan bahwa memang kualitas layanan berpengaruh signifikan pada loyalitas pelanggan

\section{Kesimpulan}

Hasil penelitian menunjukkan bahwa kualitas layanan berpengaruh positif dan signifikan terhadap loyalitas pelanggan pada Dealer Yamaha Tugu Mas Bima.Hubungan dua variebel kualitas layanan dan loyalitas pelanggan dalam kategori kuat. Pengaruh kualitas pelayanan terhadap loyalitas pelanggan sebesar $41,8 \%$ dan 58,2 $\%$ dipengaruhi oleh faktor lain yang tidak diteliti dalam penelitian ini.

\section{Daftar Pustaka}

Aryani, D dan F, Rosinta.2010. Pengaruh Kualitas Layanan terhadap Kepuasan Pelanggan dalam membentuk Loyalitas Pelanggan. Jurnal Ilmu Administrasi dan Organisasi 17 (2): $114-126$

Christian, M dan V, Nuari. 2016. Pengaruh Kualitas Layanan Terhadap loyalitas KonsumenStudi kasus: Belanja Online Bhinneka.com. Jurnal Siasat Bisnis 20(1): 33-53

Darwin, S dan Y. S, Kunto.2014. Analisis Pengaruh Kualitas Layanan Terhadap Loyalitas Pelanggan dengan Kepuasan dan Kepercayaan Pelanggan sebagai Variabel Intervening pada Asuransi Jiwa Manulife Indonesia-Surabaya. Jurnal Manajemen Pemasaran Petra 2(1): 1-12

Orel, D \&F., Kara,A. 2014. Supermarket self-checkout service quality, customer satisfaction, and loyalty: Empirical evidence from an emerging market. Journal of Retailing and Consumer Services, 21: 2013-2015.

Ghozali, Imam. 2006. Aplikasi Analisis Multivariat dengan Program SPSS. Edisi IV .BP UniversitasDiponegoro.

Hair, Joseph F. JR., Rolph E. Anderson, Ronald L. Tatham, William C. Black,2006. "Multivariate Data Analysis With Readings", 6th Edition, Prentice Hall, New Jersey.

Hardiansyah .2011. Kualitas Pelayanan Publik. Gava Media: Yogyakarta.

Putri, Y. L dan H. Utomo.2017. Pengaruh KualitasLayanan terhadap Loyalitas Pelanggan dengan kepuasan sebagai variable intervening (Studi Percepsi Pada Pelanggan Dian Comp Ambarawa. Among Makarti 10 (19): 70-90

Kotler, P., dan Armstrong, G. 2008. Prinsip-prinsip Pemasaran, Edisi 12.Erlangga. Jakarta.

Kotler, P., dan Keller, K. L. 2008.Manajemen Pemasaran, Edisi 13.Erlangga. Jakarta. 
Sugiyono.2014. Metodologi Penelitian Bisnis (Pendekatan Kuantitatif, Kualitatif, dan R\&D). Bandung : Alfabeta

Tjiptono, F. 2005. Service, Quality \&Satisfaction.Andi. Yogyakarta

Tjiptono, F. 2012. Pemasaran Strategik. Andi. Yogyakarta

Zikmund, W.G. 2003. Busisiness Research Methods. 7th Edition.Thomson South Western.

United

States

of

America 